\title{
Contested minorities - the case of Upper Silesia
}

\section{Dariusz Gierczak}

Herder Institute for Historical Research Ostmitteleuropa. Institute of the Leibniz Association, Gisonenweg Str. 5-7, D-35037 Marburg, Germany

E-mail address: dariusz.gierczak@herder-institut.de

\begin{abstract}
Upper Silesia in terms of ethnicity is a typical example of a historical region in Europe, but in fact, one of the few exceptions in contemporary Poland, where its mixed ethnic and religious structures have at least partly survived until today. While their existence had been denied by Nazi Germany (1933-1945) as well as by the Polish People's Republic (1945-1989), the emancipation of the German and Silesian minorities after the democratic changes of 1989 have evoked strong emotions in the ethnically almost uniform country. Nonetheless, the recent situation of minorities has improved as never before. Minority organisations has been officially recognized and German finally has become the second language in some municipalities of Upper Silesia, but the largest ethnic group in the whole country, the Silesians, have still experienced no formal recognition as a national minority. This article deals with the demographic aspects of the ethnic groups in Upper Silesia since the $19^{\text {th }}$ century until recent times. The census results concerning the ethnic minorities or languages in Upper Silesia have been contested since the first records of that kind have been taken. The outcomes of the both last censuses of 2002 and 2011 concerning the minority question reflected for the first time a much more realistic picture of the status quo. Furthermore, they showed that the idea of Silesian identification found an unexpected high number of supporters. This fact indicates an emerging meaning of regional identification amid significant changes of cultural values in Polish society.
\end{abstract}

KEY WORDS: historical demography, demography, minorities, Silesians

\section{Introduction}

Silesia has never been independent, but it was always under the influence of its neighbouring nations. In this Central European region, the interests of the rulers of Poland, Germany, Bohemia and Austria met. The influence of their cultures and languages on the daily life of the local population are still noticeable, especially in Upper Silesia where the continuity of the local settlement has not been interrupted, as it had happened in Lower Silesia after the World War II.

Upper Silesia in the context of this paper is seen as the area of the former German district (Regierungsbezirk) Oppeln which was the longest existing administrative unit without significant border changes in this region (1821-1920) and which covers about $13.230 \mathrm{~km}^{2}$ (Fig. 1).

When treating the history of a region with mixed population, one has to be aware of the fine difference of national and ethnical identity on the one hand and nationality and citizenship on the other. A nation is a group of people who share common history, culture, ethnic origin and language. The modern concept of a nation is closely related to the development of modern states and nationalist movements in Europe in the eighteenth and nineteenth centuries. The same or a very similar definition is often used for the description of ethnic groups. The only plausible difference seems to be that the term nation is often related to the above mentioned group of people possessing its own state, or in some cases at least a local government. Such groups which differ from the national majority by the lack of an official political body are usually treated as an ethnic group (FENTON, 2010).

However, the reference on a common ethnic origin in these definitions is obsolete, considering the large-scale migration flows and naturalization 
processes. Similar to the modern concept of nation, also the modern form of citizenship and the idea of the nation state are in general related to the French revolution. Citizenship as a legal status came first to the territory of Silesia at the time of the Prussian rule in the $19^{\text {th }}$ century. With its introduction, all members of other ethnic minorities permanently living in Prussia - like the Slavonic population of Upper Silesia - became Prussian citizens. As the German citizenship was introduced in 1934, instead of state (Länder) citizenship, the population of Silesia became German citizens (REICHSGESETZBLATT, 1934).

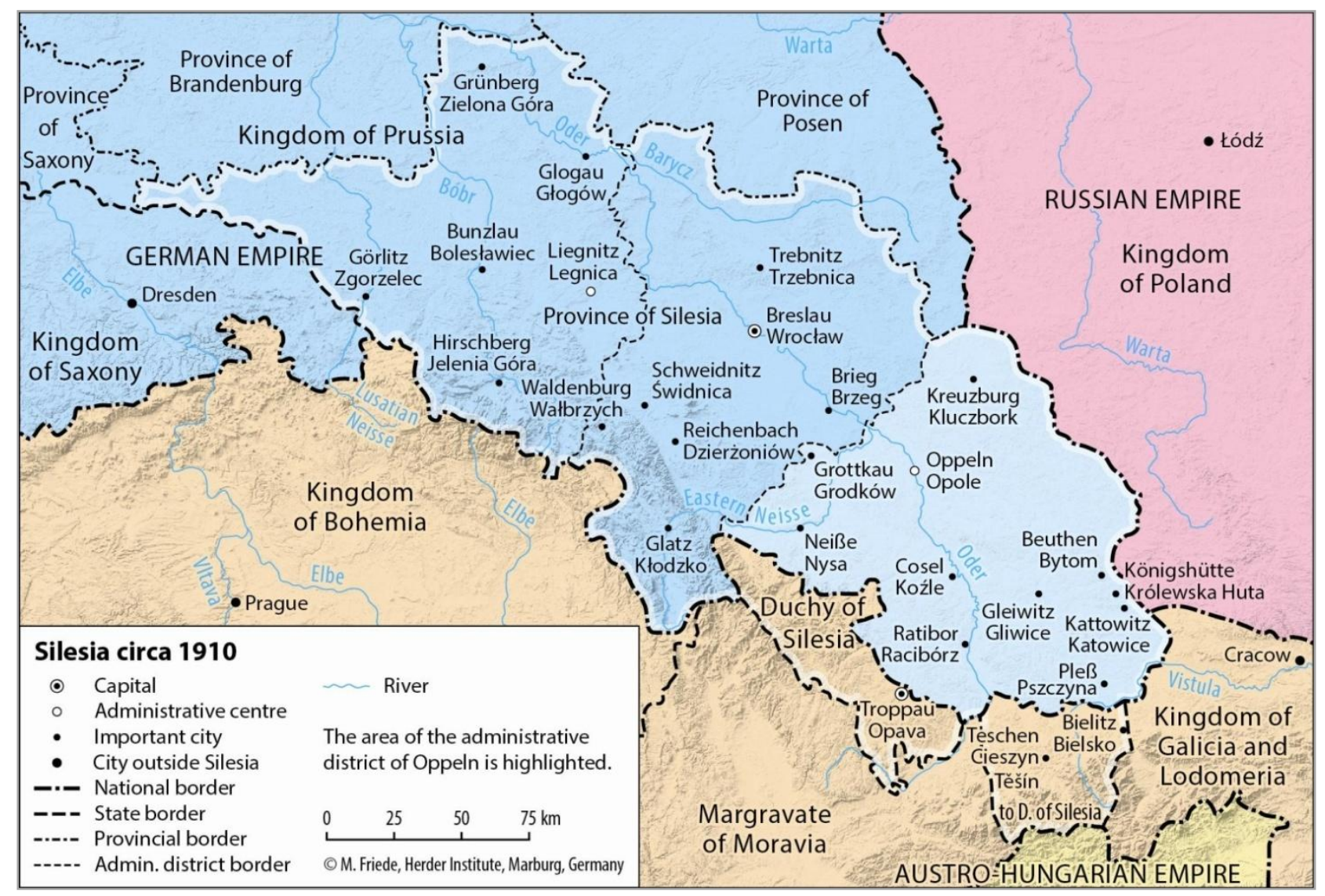

Fig. 1. Location of the district of Oppeln within the province of Silesia (after Marc Friede, Herder Institute, Marburg)

After World War II the remaining population of Upper Silesia received Polish citizenship, but they and their descendants had also the right to receive the German one. The right for dual citizenship was de facto accepted by Poland in 1990 (KAMUSELLA, 2003b).

There are not many reliable numbers on the ethnic composition of the population in Prussia. Some Prussian censuses which were taken more or less every five years collected data about the mother tongue, but only the censuses in Nazi Germany from 1933 and 1939 registered the ethnic origin (Volkszugehörigkeit). But especially these data seem in face of the Nazi terror untrustworthy.

The upper class as well as the middle class of Upper Silesia spoke German at least since the second half of the $19^{\text {th }}$ century, while the Silesian dialect was the language of the lower classes. Silesian used in Upper Silesia is a dialect of the Polish language with frequent archaisms and
German words (HEnTSCHEL, 2002), but some linguists support its status as a language (KAMUSELLA, 2003a). For the speakers, however, the language never coincided with the national consciousness. Due to their affiliation to the German (or Prussian) state a large part of the speakers considered themselves as Germans. Others called themselves Silesian and only a small part identified themselves with Poland, if indeed (considering the lack of relations with the other parts of the Polish population during the 700-800 years of German influences and partly indirect control over Silesia). Furthermore, after the transfer of Silesia to Poland the remained locals more and more identified themselves with Poland and the Polish nation, while many others emigrated. The situation persists until today, and the group of speakers of any language or dialect in Upper Silesia do not match with their national or ethnic identification (LESIUK, 2003). 
Only the first census in Polish People's Republic after World War II (1946) recorded the nationality. Due to the political doctrine of the one-nation state there had been no newer data about nationality or language until 2002 when the first census after the democratic change in Poland was taken. This census registered the nationality and the language used at home as well. Furthermore, the participants of the last census from 2011 had the opportunity to name a second ethnicity.

Surprisingly, the number of people identified themselves with Silesian showed a strong increase between the both last censuses making them the by far largest minority group in Poland far ahead of Germans, the second largest one. It caused consternation in the public debate in Poland and many saw it as a threat to the cohesion of the Polish state. However, on the meantime, the transformation led to profound social changes which included also changes of social values. In face of the newly found freedom to travel and increasing international and intercultural interactions, especially after joining the EU in 2004, the social relevance of national identification declines, while the local and civic identifications is becoming more important (DUNIN, 2004; JASIŃSKAKANIA, 2012).

From the point of view of social development, the demographic development of Upper Silesia can be divided into five phases which are discussed in the following chapter. Because of the several changes of the state affiliation of the area the place names are given in Polish and German on their first occurrence and hereinafter in the currently official language (e.g. Polish).

\section{The ethnic demographics of Upper Silesia}

\subsection{Phase I: The ethnic and demographic development of Upper Silesia before industrialisation}

Slavonic tribes settled in Upper Silesia during the Early Middle Ages. Since the $12^{\text {th }}$ century, the Silesian dukes recruited settlers and knights from the Holy Roman Empire, which were mostly Germans. These settlers gradually integrated themselves into the Slavonic population, but later on the German culture and language dominated and attracted especially the members of the nobility. The German population dominated in the towns where they soon were in charge of the administration and the trade. The much larger rural population was mostly Slavonic speaking. The demographic losses in the towns were balanced partly with the peasants from surrounding rural areas, and partly with new settlers from Germany and Bohemia (ŻERELIK, 2002).

As the Silesian duchies came under Czech rule in the $14^{\text {th }}$ century, they became border regions of the empire. The Czech and Moravian influences were noticeable especially in the southern part of Silesia, also in the local dialect (HENTSCHEL, 2002). After the Prussian annexation of Upper Silesia 1740/42 German replaced Bohemian as the official language (KAMUSELLA, 2003b).

In some larger settlements also Jewish communities evolved. The share of Jewish population oscillated between 1-2\%, and dropped down, as well as the absolute numbers, during the phase of industrialisation. With rare exceptions, they spoke German and lived in the urban centres.

After the long period of German rule, German dominated in the cities as the official language. Unlike in Lower Silesia, where the Slavonic languages (Polish and Czech) - and the Slavonic consciousness - had with some exceptions disappeared during the $18^{\text {th }}$ century, Slavonicspeaking population still dominated in Upper Silesia. The very bearing idea of a national state did not show its influences in this remote and sparsely inhabited land. This region situated on the eastern outskirts of Prussia did not receive much attention until the industrial revolution. The quickly spreading industrialisation was based on steam power which depended on coal and iron ore resources. Large amounts of hard coal and iron ore were deposited in the yet less developed eastern part of the region.

\subsection{Phase II: Industrialisation and its consequences} for the population in Upper Silesia

In 1816 there were 524,784 inhabitants in Upper Silesia. The largest town at this time was Nysa/Neisse with a population of about 8,541, followed by Racibórz/Ratibor with 4,505 and Opole/Oppeln with 4,050 inhabitants. The largest one in the later industrial area which is today the most populated part of this region was Gliwice/ Gleiwitz (3,163 inhabitants).

Apart from the Ruhr district Upper Silesia was one of the first areas in continental Europe which underwent very dynamic economic and social changes due to industrialisation. With the beginning of the industrial revolution a large number of migrants entered the cities and towns, particularly in the present Upper Silesian industrial region. The majority of the new urban population was Silesian coming from the surrounding rural areas (ENGEL, 1875). The increasing number of civil servants and other officials in the Upper Silesian 
cities and towns came, however, from other provinces of Prussia and spoke German only. A growing part of the Slavonic population in the urban areas assimilated with the German population, particularly as the Polish language meant social disadvantage. The Polish (Silesian) speaking population in Upper Silesia consisted mostly of unskilled workers and peasants lacking middle class status and economy power (LESIUK, 2003). On the other hand, in aftermath of the 1848 revolutions, numerous initiatives of local pro-Polish activist began, who were partly supported by campaigners from the other eastern Prussian provinces, as well as from Habsburg Galicia and Congress Poland. Among other things, they published several magazines and other print publications in Polish. However, Polish mattered for the local population essentially as a liturgical language since they identified themselves primarily by their Catholic religion and not by language.

In 1861 (Fig. 2), the German language dominated only the south-western fringes of Upper Silesia with the city of Nysa (100\%) and the districts Grodków/Grottkau (100\%), Niemodlin/Falkenberg (89\%), and Głubczyce/Leobschütz (82\%). The second largest language group in the last mentioned district was the Czech (16\%) which appeared also in a higher share in the county of Racibórz (37\%), but still, there were more Polish speakers (45\%). A slight domination of the German language over the Polish was reported in the district of Prudnik/Neustadt (51\% vs. 49\%). In other eleven districts the share of German speakers was between 10 and 27\% (TRIEST, 1864).

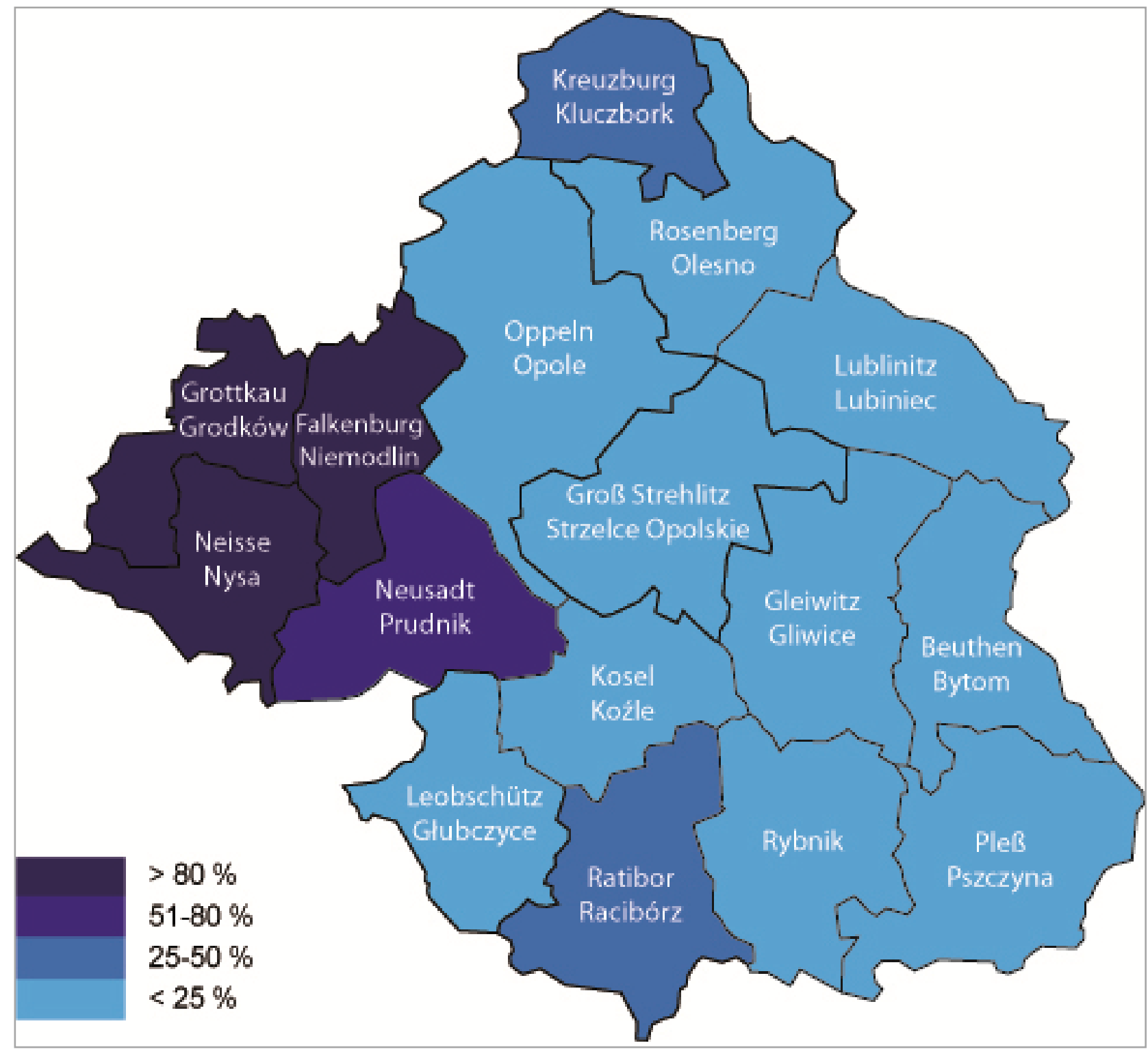

Fig. 2. German speaking population in Upper Silesia 1861 (source: own computation, based on 1861 Prussian census results) 
Among the German speakers were also the Jews (in 1871: 22,766 persons, e.g. $1.7 \%$ of the entire population of $1,309,563$ ). More than a half of this relatively small group of people which differed from the Germans in a religious, cultural, and ethnic sense, lived in urban areas (where only $21 \%$ of whole population of Upper Silesia were living). Especially in the industrial cities Jewish communities of considerable size emerged: Gliwice (14.6\%), Mysłowice/Myslowitz (12.5\%), Bytom/Beuthen (11.6\%), Katowice/Kattowitz (11.1\%). During the next decades the number of Jews in Upper Silesia stagnated whereas the whole population rose rather rapidly ${ }^{1}$.

Since the 1860s the population of Upper Silesia increased due to the natural increase (Volz, 1922). The records from the census in 1885 show that only $2 \%$ of the inhabitants within the district of Oppeln were born outside of the province of Silesia. In the urban areas in the industrial region their share was slightly higher: $3-5 \%$. The global share of migrants was in this part of Upper Silesia, however, distinctly higher. While in the whole district $60 \%$ of its population was born in the same place, but in the city of Bytom it was only $37 \%$ (KÖNIGLICH PREUßISCHES STATISTISCHES BUREAU, 1888).

During the period of intensive industrialisation the essential features of the modern concept of urban planning emerged: the town became an open urban structure which did not stop at natural or administrative borders. Where there once had been small villages, now large worker settlements emerged which either gradually became towns or merged into the nearest large extending town. Especially the industrial cities and towns grew very fast. The city of Królewska Huta/Königshütte (founded only in 1869 and amalgamated 1934 with Chorzów) outnumbered in 1871 the population of Nysa $(19,536$ vs. 19,367). Królewska Huta was the fastest growing place in Upper Silesia and its population had increased 18 times since 1861. The six fastest growing urban places in Upper Silesia, which doubled their population, were all located in the present Upper Silesian industrial region. From the eight cities and towns with a population number over 10,000 two more towns where located in this area (Bytom: 15,771 and Gliwice: 12,937). Before World War I the five most populated places of Upper Silesia were situated in the industrial district. The largest one, Królewska Huta $(72,649$ in 1910), was with Katowice $(43,173)$ and the rural community of Zabrze (later renamed as

\footnotetext{
${ }^{1}$ During the $19^{\text {th }}$ century the growth rate of the entire population was among the highest in Germany
}

Hindenburg by the German authorities after the general Paul von Hindenburg, 63,373) among those places which history had first begun with the industrialisation. The population of both Bytom and Gliwice reached above 65,000.

During the industrialisation phase the pressure of national and ethnic assimilation increased, especially after Otto von Bismarck was appointed prime minister of Prussia in 1862 (LIS, 2001). This is reflected in the language statistics (Fig. 3) which gave for 1910 higher shares of German speakers than in 1871 in the most of the districts of Upper Silesia but Strzelce Opolskie/Groß-Strehlitz. Also in Nysa and its rural surroundings as well as in Grodków the generally very low share of Polish speaking population increased by $1-3 \%$. 53\% from 2,207,981 inhabitants were Polish speakers (or $57 \%$ including bilingual persons). Their share within rural areas was $64 \%$ (or $67 \%$ ), but in urban areas it was only $22 \%$. Simultaneously the number of the bilingual persons (German and Polish) increased, especially in the urban areas $(6 \%)$ (ENGEL, 1875; KÖNIGLICHES STATISTISCHES LANDESAMT, 1912). German sources classified these persons as Germans, though, as there were usually no convincing reasons for Germans to learn Polish, the increasing bilingualism could be seen as an expression of the assimilation pressure.

Numerous German sources quoted results of various ballots carried out in Upper Silesia in order to show that the number of Polish minded population is much lower than the number of Polish speakers. So in 1912 the votes for Polish delegates received $30-50 \%$ less than the number of the Polish speaking population (REICHSVERBAND OSTSCHÜTZ, 1919). The question of ethnicity seemingly did not belong to the preferences of the voters and there was a large variation of the vote share in favour of the Polish candidates like the ballots from 1919 showed, when $55 \%$ of all votes within the later plebiscite area fell on Polish candidates (LESIUK, 2003).

\subsection{Phase III: The partition of Upper Silesia}

The restored Polish state and the new Czechoslovakian state which emerged after World War I had a common interest in Upper Silesia. The only area in Silesia with Czech majority, a small part of the county of Racibórz - Hultschiner Ländchen (Czech: Hlučínsko), was transferred on January 10 1920 to Czechoslovakia $\left(3,159 \mathrm{~km}^{2}\right.$ with 48,446 population of which 7,173 or $14.8 \%$ were German language speakers, 38,508 or $79.5 \%$ Czech speakers and about 5,7\% Polish) (KelLer, 1919). 
The Allies occupying Upper Silesia decided to hold a plebiscite and divide the remaining region between Poland and Germany. The period of the plebiscite campaign was marked by violence from both the German and Polish sides. Two Polish uprisings (1919 and 1920) took place before the plebiscite and another one a short time after, in May 1921.

The plebiscite from March 201920 was attended by $1,186,758$ people of which $59.6 \%$ voted for Germany and $40.4 \%$ for Poland. Again, the numbers of pro-German voters were much higher in the large urban areas and their vicinities, while in numerous rural communities Poland got more votes. Both sides insisted on the inseparability of the plebiscite area $\left(10,886 \mathrm{~km}^{2}\right)$, but due to the complicated results with the dispersed distribution of the votes, the League of Nations decided to split up this area. Poland obtained $3,213 \mathrm{~km}^{2}$, including the greater part of the Upper Silesian industrial district and more than $80 \%$ of the heavy industry of the region. The Polish part was inhabited by 985,076 persons in 1919 (FLOTT, 1937; see also STRUVE, 2003).

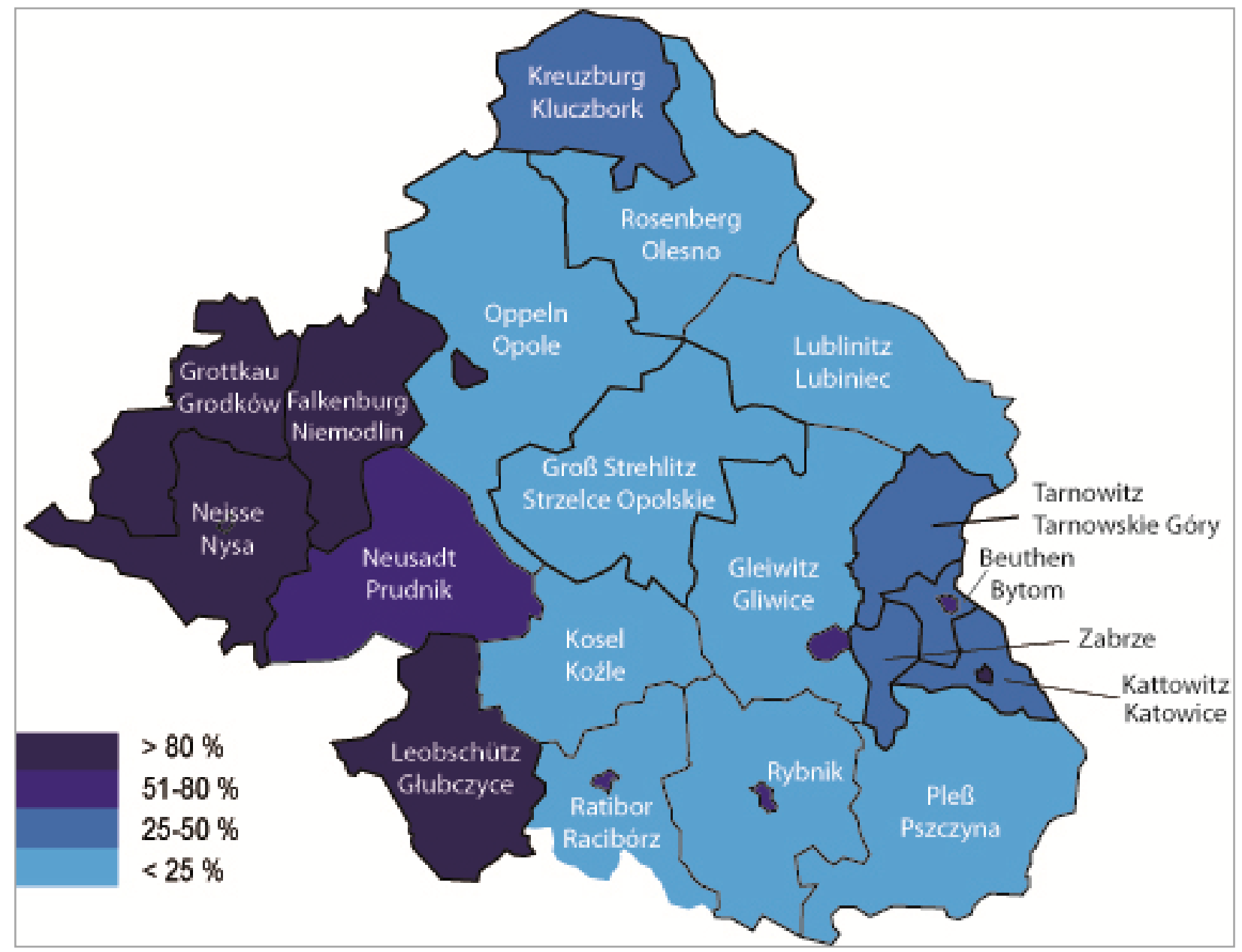

Fig. 3. German speaking population in Upper Silesia 1910 (source: own computation, based on 1910 Prussian census results)

The partition caused population exchanges. According to various sources, about 120-200,000 Germans left the Polish part of Upper Silesia, about 100,000 of them just before the partition, while 40-100,000 persons migrated in the opposite direction (FLOTT, 1937; KAMUSELLA, 1999, KOSIŃSKI, 2005).

Polish sources gave a higher number of Poles in the Polish part of Upper Silesia due to the number of school children as established by the census of 1911. These numbers were extrapolated in accordance with the 1919 population figures and resulted in 815,606 or $83.2 \%$ Poles and 164,690 or $16.8 \%$ others. The capital of the Polish part - Katowice should have $67.9 \%$ Polish population. In the entire voivodeship Silesia there were 1,124,967 inhabitants of which 926,265 were Poles (82.3\%) in 1921 and respectively $1,298,352$ and 1,198,191 (92.3\%) in 1931. However, the results of the Polish censuses have been questioned. Furthermore, the first one did not even take place in Upper Silesia. The ethnicity referred in fact to the mother tongue as recorded in census (KRYSIŃSKI, 1933). 
The Polish voivodeship of Silesia which included also parts of the western areas of former Austrian Silesia received extended autonomy rights. Polish became the most widespread language there. After the autonomy was curbed and the international minority protection acts (Geneva Convention) expired, the repressions of Germans in Polish Upper Silesia increased significantly. In the first decade of $20^{\text {th }}$ century the pro-Silesian movement began to grow. A huge group of the local population on both sides of the border fought for the recognition of a Silesian nationality, but their leaders were persecuted as well in Germany as in Poland after the partition of Upper Silesia (KAMUSELLA, 1999).

The census from 1933 recorded 99,193 persons with Polish as the only mother tongue and 266,375 persons with both, Polish and German native languages in the German part of Upper Silesia, i.e. together $25 \%$ from the total of $1,482,865$. Considering the assimilation pressure under Hitler and the generally hostile attitude towards Poland in Germany in those times, the sharp decreased numbers (down from about 505,000 or $36.6 \%$ in 1925) (FLOTT, 1937) were still surprisingly high. Modern Polish estimated of Poles/Silesians in the region put the figure of 480,000-750,000 as of 1939 (LESIUK, 1990).

\subsection{Phase IV: World War II and its influences on the ethnic composition of the population in Upper Silesia}

After the German aggression on Poland in 1939 the German province Upper Silesia was extended by including the Polish voivodeship Silesia with some enlargements. The Germans maintained the same regional population policy in the occupied areas of Upper Silesia as in the western part of the region. Heinrich Himmler, Reich Commissioner for the Strengthening of the German National Character (Reichskommissar für die Festigungdeutschen Volkstums), ordered a persistent policy of Germanisation of Upper Silesia. 98\% of the population of this region was categorised in accordance to the so called Deutsche Volksliste which included four categories: I. Volksdeutsche - Persons of German descent who had engaged themselves in favour of the Reich before 1939 $(100,000$ persons in the eastern part of Upper Silesia), II. Persons of German descent who had remained passive concerning the disclosure of their nationality before 1939 (200,000), III. Local inhabitants considered as partly polonised $(900,000)$, and IV. Non-supporters of the Reich whose nationality was considered as "racially valuable" $(55,000)$. Unlike in other parts of Poland, this categorisation was not voluntary in Upper Silesia. Until 1944 the last Jews living in Upper Silesia $(88,746$ persons according to the German census in the Katowice region in 1939/40 and 4,377 in the pre-war German part of the province in 1939) were taken to concentration camps and murdered. There were only few survivors. About 37,000 Poles had been forced to leave Upper Silesia and they were replaced by a similar number of German settlers from the Soviet Union (HOENSCH, 1998).

The largest relocation of the Upper Silesian population in history which had begun during the World War II culminated just after the war. The Polish authorities refused Germans who had fled from the Soviet army to stay in Poland. The remaining local population had to prove their Polish nationality to the Verification Commission in order to stay. 86,000 persons from Upper Silesia were expelled to Germany and 65,000 taken to the USSR as forced labourers. 1945-1947 about 40,000 died in the former Nazi-German camps which became concentration camps (e.g. Łambinowice/Lamsdorf and Świętochłowice/ Schwientochlowitz) for Germans and inconvenient Upper Silesians (KAMUSELLA, 1999).

After World War II the new Polish rulers considered the multicultural character of Upper Silesia as a threat for the Polish claims on this territory. As in the pre-war voivodeship of Silesia - and similar to the Prussian times, when the officials in Upper Silesia had come from the other provinces - also after the war the highest and decision-making positions were given to Poles from outside the region. The remained locals were excluded from power and administrative structures. Despite the "verification" and "re-polonisation", the communist rulers did not trust the local population, particularly as the Verification Commission worked negligently in some places, at least, because the Polish state was interested in skilled workers and specialists to work in the mines and heavy industry. Even the "verified" Silesians were considered as pro-German and as potential enemies of the state, also because of their differing from the standard Polish language. The regional dialect was ousted from public life. In the face of these experiences, many Silesians separated themselves from the incomers (LIS, 1993).

Meanwhile the population of the cities in Upper Silesia, especially in the industrial district, increased. Already in 1950 all the main cities of the region had a higher population than in 1939. Due to the strong support of heavy industries from the state, the relatively rich region gained 
in-migrants from the entire country who could easily find a well-paid job.

According to the Polish registries from February 1946 there were 2,813,748 Persons in Upper Silesia, 827,500 (29\%) of them Poles. On September 15 1946 there were 1,285,340 Persons, among them 162,300 from other parts of Poland, and 295,500 from the pre-war Polish territories in the USSR (SuBoczoWA, 1948). When the "verification" process ended in 1949, 866,600 Upper Silesians were positive verified. Until 1950 about 24,772 Polish repatriates from Western Europe (France, Germany) settled in Upper Silesia (LIS, 1991). Due to the politic and economic situation in Poland and the social disadvantages of the Silesian population, a large part of the positive "verified" persons decided to leave for Western Germany. This became possible during the "Polish thaw" (Polish October) in 1956-1958 within the framework of family reunion (many families had relatives who had failed the "verification"). In spite of strong border restrictions which existed until the end of 1980s, in the years 1971-1998 more than 440,000 Upper Silesians arrived in Western Germany as so called Aussiedler (i.e. German natives immigrate according to German law) (KAMUSELLA, 1999; figures after STATISTISCHES BUNDESAMT, 1973-2001). The numbers of Silesians living since generations in the regionwas estimated at about 500,000 (LIS, 1991; RAUZIŃSKI ET AL., 1996).

\subsection{Phase V: After the democratic changes of 1989}

Already at the beginning of the democratic changes in Poland in 1989 minority organisations were allowed, and after long years of forced absence, German was taught in many schools throughout Upper Silesia and German minority organisations could take part in the social and political life. The concerns of many Poles that Germany would now make claims to these territories, turned out to be unfounded. In fact, the expellees had gave up the idea of returning to their old homeland in the 1950 s, despite their statements to the contrary in the public debate (DEMSHUK, 2012).

According to the number of the German minority organisations in the region, there were about 300,000 Germans expected in Upper Silesia before the census took place. In fact, a high number of Silesians had joined the German minority organisations since the 1990s just because this was a possibility to differ from the predominant Polish culture and language after the years of statedriven standardization attempts (LIS, 1993: 63-98).

After the years of emigration of the native Silesians on the one hand, and the in-migration of Poles from other parts of the country on the other, the native Silesian population, remained a minority. In the census of 2002 they got for the first time the possibility to declare themselves as Silesians (Table 1) (census results 2002 and 2011: www.stat.gov.pl). Surprisingly, according to these results the Silesians became the second largest minority group in Poland alongside the Germans. Despite of some reported incidents as the census interviewer denied recording a declaration of Silesian nationality into the form (http://www. naszekaszuby.pl/modules/news/print.php?storyid= $23)$, there were 171,840 Silesians $(4.8 \%$ of $3,228,915)$ and 134,695 Germans (3.8\%) counted in Upper Silesia.

Table 1. Ethnic composition of the largest cities in Upper Silesia 2002 (own computation based on 2002 Polish census results)

\begin{tabular}{|l|c|c|c|c|}
\hline \multicolumn{1}{|c|}{ City } & Total population & Polish [\%] & German [\%] & Silesian [\%] \\
\hline Zabrze (Hindenburg) & 195,293 & 81.1 & 1.4 & 2.1 \\
\hline Katowice (Kattowitz) & 327,222 & 90.7 & 0.2 & 5.5 \\
\hline Chorzów (Königshütte) & 117,430 & 87.6 & 0.3 & 6.1 \\
\hline Gliwice (Gleiwitz) & 203,814 & 89.5 & 1.1 & 1.1 \\
\hline Bytom (Beuthen) & 193,546 & 83.7 & 1.3 & 3.9 \\
\hline Opole (Oppeln) & 129,946 & 89.9 & 2.7 & 0.7 \\
\hline Ruda Śląska (Ruda) & 150,595 & 90.2 & 0.3 & 5.6 \\
\hline Rybnik & 142,731 & 88.9 & 0.3 & 6.5 \\
\hline Tychy (Tichau) & 132,816 & 96.0 & 0.2 & 1.2 \\
\hline Jastrzębie-Zdrój (Bad Königsdorff-Jastrzemb) & 97,116 & 96.2 & 0.2 & 1.1 \\
\hline
\end{tabular}


Table 2. Ethnic composition of the largest cities in Upper Silesia 2011 (own computation based on 2011 Polish census results)

\begin{tabular}{|l|c|c|c|c|}
\hline \multicolumn{1}{|c|}{ City } & Total population & Polish [\%] & German [\%] & Silesian [\%] \\
\hline Zabrze (Hindenburg) & 181,128 & 90.0 & 1.4 & 14.6 \\
\hline Katowice (Kattowitz) & 310,764 & 86.4 & 0.3 & 25.4 \\
\hline Chorzów (Königshütte) & 111,693 & 80.2 & 0.6 & 33.8 \\
\hline Gliwice (Gleiwitz) & 187,475 & 93.7 & 1.3 & 9.7 \\
\hline Bytom (Beuthen) & 176,902 & 83.7 & 1.4 & 17.6 \\
\hline Opole (Oppeln) & 122,625 & 95.1 & 2.0 & 3.7 \\
\hline Ruda Śląska (Ruda) & 142,510 & 78.7 & 0.6 & 35.8 \\
\hline Rybnik & 140,924 & 85.2 & 0.5 & 27.9 \\
\hline Tychy (Tichau) & 129,378 & 92.2 & 0.2 & 16.5 \\
\hline Jastrzębie-Zdrój (Bad Königsdorff-Jastrzemb) & 92,465 & 96.1 & $<0.4$ & 9.9 \\
\hline
\end{tabular}

The first published results of the last census taken in 2011 (Table 2) have shown unexpected high increase in numbers of Silesians and high decrease of Germans. The aggregation level of the first results does not allow a direct comparison with the 2002 census for the whole former district of Oppeln. Still, it shows that the increase of Silesian was extremely high in the largest cities of the region, amid high population losses. The use of Silesian language (that most linguists in Poland consider Silesian as a dialect of Polish) declared more people in urban places than in villages.

Paradoxically, it has been easier to accept the existence of a large German minority in Poland than a Silesian one. The unexpected rise of the Silesian minority caused consternation, as many saw it as a threat to the cohesion of the Polish state. The statement of the former Prime Minister and the leader of the Law and Jusitice (PiS) from April 2011, is characteristic for the Polish rightwing politicians: "Being a Silesian is a simple way to cut ties [with a Polish identity], and indeed could be a way to camouflage a German identity." (www.newpolandexpress.pl).

The consideration of the Silesians as an ethnic minority still remains controversial in the Polish public debate. While numerous publications and other local initiatives emerged, like the reestablished football club 1. FC Katowice, the registration of Silesian national organisations has been partly refused. Polish courts (like the Supreme Court 1998, 2007, and 2013) consistently reject the registration of organisation including Silesian nation in their name, arguing the existence of such a nation. The situation that a court decides on the ethnicity seems to be unique in democratic states.

Surprisingly, the numbers of people who declared Silesian nationality is higher as the calculated numbers of the locals living since generations in Upper Silesia (RAUZIŃSKI ET AL., 1996). It seems to confirm the results of a genetic study from the United Kingdom which, among others, found no significant differences between the Scots and the English. This is an indication that the ethnic groups in a modern, mobile society are, above all, social constructions (LESLIE ET AL., 2015).

Since the political changes of 1989 the Polish society underwent profound social changes which included also changes of social values. In face of the newly found freedom to travel and vivid interactions with people from other countries and cultures, especially after joining the EU in 2004, the social relevance of national identification declined, while the importance of local and civic identifications increased (DUNIN, 2004; JASIŃSKA-KANIA, 2012). The Phenomenon of the rapidly growing Silesian minority can be partly explained by the rising emancipation of the local population in a pluralistic society which has been formed in Poland since the beginning of the transformation which allowed free expression of identification on the one hand, but relativized the national identification on the other.

\section{Conclusion}

During the four phases of the demographic development the ethnic composition of the population in Upper Silesia underwent substantial 
changes. During phase I, before the industrialisation, the rural region was populated by Slavic people speaking a Polish dialect without a distinctive national consciousness. The increasing numbers of German colonists and the members of the nobility spread the German language which became attractive, first for the upper class.

In Phase II the repressive politics of Prussia against the Polish language in favour of German, the social disadvantage related to the lack of knowledge of the German language resulted in the assimilation with the Germans. Assimilation progressed especially in the extremely fast growing urban areas - where the German language and culture dominated as early as in phase I - and in the western part of the region.

The interwar years 1918-1939 marked the phase III in which Upper Silesia were divided between Poland and Germany (a small part was transferred to Czechoslovakia). At the beginning of this phase three uprisings of the Polishdedicated population took place. After some more or less voluntary population exchanges between Poland and Germany, the population composition of the both part of Upper Silesia changed, according to the currently in power. The assimilation pressure in Germany increased, especially after 1933. The new formed Polish state exerted assimilation pressure, especially on the German Silesians. 1939 Germany took over the Polish territory and lead the same regional population policy in the whole Province of Upper Silesia, in which the occupied Silesian areas were immediately included.

The next phase begun after World War II with the expulsion of the remaining German population. The Verification Commission declared the Polish nationality of the local population, since the afterwar Poland claimed to be an ethnic homogenous state. The ethnic composition of the population underwent substantial changes, as the evacuees from the former Polish territories in the USSR replaced the German speaking population. After some time, a significant part of the once positive "verified" population left for Germany, where they were exposed to the pressure of social assimilation as in Poland. The recent situation of minorities after the democratic changes of 1989 improved. Minority organisations were allowed and Germans finally enjoys a full recognition in, including the political representation in the state parliament.In the 2000s Silesian became the by far largest minority countrywide. However, the consideration of the Silesians as an ethnic minority still remains controversial in the Polish public debate, although the social relevance of national identification decrease in face of changing social values in favor of local and civic identification. The ethnic affiliation in a modern, mobile society is a social construct, and therefore the rising of Silesians can be considered as an effect of the emancipation of the local population in the pluralistic civil society which develop in Poland after 1989.

\section{References}

Demshuk A. 2012. The Lost German East. Forced Migration and the Politics of Memory, 1945-1970. Cambridge.

Dunin K. 2004. Czytając Polskę. Literatura polska po roku 1989 wobec dylematów nowoczesności. Warszawa.

Engel Dr. (ed.) 1875. Die Ergebnisse der Volkszählung und Volksbeschreibung im Preussischen Staate vom 1. December 1871. Berlin.

Flott F. 1937. Oberschlesische Frage, Breslau.

Hentschel G. 2002. Schlesisch. [in:] Okuka M., Krenn G. (eds) Lexikon der Sprachen des Europäischen Ostens. Klagenfurt: 437-442.

Hoensch J.K. 1998. Geschichte Polens. Stuttgart.

Jasińska-Kania A. (ed.) 2012. Wartości i zmiany. Przemiany postaw Polaków w jednoczącej się Europie. Warszawa.

Kamusella T. 1999. The Dynamics of the Policies of Ethnic Cleansing in Silesia in the Nineteenth and Twentieth Century. Budapest.

Kamusella T. 2003a. The Szlonzoks and their Language: Between Germany, Poland and Szlonzakian Nationalism. EUI Working Paper HEC 3/2001.

Kamusella T. 2003b. Dual citizenship in Opole Silesia in the context of European integration. Facta Univ., Philosophy, Sociology and Psychology, 2/10: 699-716.

Keller K. 1919. Die fremdsprachige Bevölkerung in den Grenzgebieten des Deutschen Reiches. Berlin.

Königlich Preußisches Statistisches Bureau (ed.) 1888. Die endgültigen Ergebnisse der Volkszählung vom 1. Dezember 1885 im Preußischen Staate sowie in den Fürstentümern Waldeck und Pyrmont, Berlin.

Königliches Statistisches Landesamt (ed.) 1912. Gemeindelexikon, 6, Regierungsbezirk Oppeln. Berlin.

Kosiński L. 2005. Plebiscyty na Powiślu, Warmii i Mazurach oraz na Górnym Śląsku. [in:] Gawryszewski A. (ed.) Ludność Polski w XX wieku. Warszawa: 543-546.

Krysiński A. 1933. Ludność polska a mniejszości w Polsce $w$ świetle spisów ludności 1921 i 1931, Warszawa.

Lesiuk W. 2003. Die Enstehung und Entwicklung des deutsch-polnischen Konflikts in Oberschlesien zu Beginn des 20. Jahrhunderts. [in:] Struve K. (ed.) Oberschlesien nach dem Ersten Weltkrieg. Studien zu einem nationalen Konflikt und seiner Erinnerung, Marburg: 33-45.

Lesiuk W. 1989. Ludność etnicznie polska na Śląsku w czasie II wojny światowej - próba zobiektywizowania ocen niemieckich i polskich. Opole. [in:] Lis M. (ed.) Polska ludność rodzima na Śląsku $w$ okresie Polski Ludowej. Opole: 7-36.

Leslie S., Winney B., Hellenthal G., Davison D., Boumertit A., Day T., Hutnik K., Royrvik E.C., Cunliffe B., Wellcome Trust Case Control Consortium 2, Int. Multiple Sclerosis Genetics Consortium, Lawson D.J., Falush D., Freeman C., Pirinen M., Myers S., Robinson M., Donnely P., Bodmer W. 2015. The fine-scale genetic structure of the British population. Nature, 519, 2015: 309-314.

Lis M. 1991. Polska Ludność rodzima na Śląsku po II wojnie światowej (polityczno-społeczne uwarunkowanie integracji). Próba syntezy. Opole. 
Lis M. 1993. Ludność rodzima na Śląsku Opolskim po II wojnie światowej (1945-1993). Opole.

Lis M. 2001. Górny Śląsk. Zarys dziejów do połowy XX wieku. Opole.

Rauziński R., Grygierczyk M., Szczygielski K. 1996. Stosunki narodowościowe i demograficzne na Śląsku opolskim, 1945-1995. [in:] Frątczak E., Strzelecki Z. (eds) Demografia $i$ społeczeństwo Ziem Zachodnich i Północnych 1945-1995. Próba bilansu. Warszawa: 170-195.

Reichsgesetzblatt, I, 1934: 85.

Reichsverband Ostschütz (ed.) 1919. Ist Oberschlesien polnisch? Die polnisch sprechende Bevölkerung nach der Volkszählung vom Jahre 1910 und die abgegebenen polnischen Stimmen bei den Reichstagswahlen im Jahre 1912, Berlin.

Statistisches Bundesamt (ed.) 1973-2001. Statistisches Jahrbuch für die Bundesrepublik Deutschland. Wiesbaden.

Suboczowa M. 1948. Dane statystyczne. [in:] Lutman R., Popiołek K. (eds) Śląsk. Ziemia i Ludzie. Katowice Wrocław: 242-246.
Struve K. (ed.) 2003. Oberschlesien nach dem Ersten Weltkrieg. Studien zu einem nationalen Konflikt und seiner Erinnerung. Marburg.

Triest F. (ed.) 1864. Topographisches Handbuch von Oberschlesien. Breslau.

Volz W. 1922. Oberschlesien und die oberschlesische Frage. Breslau.

Żerelik R. 2002. Dzieje Śląska do 1526 roku. [in:] Czapliński M., Kaszuba E., Wąs G., Żerelik R. (eds) Historia Śląska. Wrocław: 14-116.

www.stat.gov.pl [Główny Urząd Statystyczny, Warszawa/ Central Statistical Office, Warsaw] (accessed 5 Mai 2015).

www.naszekaszuby.pl [Nasze Kaszuby: Pomorski portal społecznościowy] (accessed 23 January 2015).

www.newpolandexpress.pl [New Poland Express] (accessed 29Mai 2015). 